\title{
Using cover measurements to estimate aboveground understorey biomass in Maritime pine stands
}

\author{
Annabel J. Porté ${ }^{*}$, Jean-Charles SAMAlens ${ }^{2,3}$, Raphaël Dulhoste ${ }^{1,4}$, Rémi TeISsier Du CRos ${ }^{5}$, \\ Alexandre Bosc ${ }^{1}$, Céline MEREDIEU ${ }^{1}$ \\ ${ }^{1}$ INRA, UR1263 EPHYSE, 33140 Villenave d'Ornon, France \\ ${ }^{2}$ INRA, UMR1202 Biodiversity Genes \& Communities, 33612 Cestas, France \\ ${ }^{3}$ Université Bordeaux 1, UMR1202 Biodiversity Genes \& Communities, 33405 Talence, France \\ ${ }^{4}$ ICAE-Facultad de Ciencias, Universidad de Los Andes, 5101 Mérida, Venezuela \\ ${ }^{5}$ IFN, Forest National Inventory, 33000 Bordeaux, France
}

(Received 8 October 2007; received version 16 May 2008; accepted 19 September 2008)

\author{
Keywords: \\ biomass / \\ understorey / \\ allometric model / \\ Pinus pinaster / \\ upscaling
}

\begin{abstract}
- Understorey plays a major role in forest fluxes and stocks balances, however this compartment is generally poorly quantified. Our objectives were to establish models to estimate understorey biomass using vegetation cover measurements and to investigate upscaling methodologies from stand to regional level.

- Understorey aboveground biomass measurements were undertaken in Maritime pine stands of mesohygric, mesic and dry moorlands in South West France.

- Average biomass stock in this compartment was estimated to $3.50 \mathrm{t} \mathrm{DM} \mathrm{ha}^{-1}$. The more abundant species groups varied with moorland types, with a higher relative contribution of herbaceous species $(23.3 \%)$, bracken $(59.2 \%)$ and mosses $(31.6 \%)$ for mesohygric, mesic and dry moorlands, respectively. For each species group, we established significant relationships to estimate biomass using a volumetric index, based on cover and height measurements. No relationship between stand characteristics and understorey biomass was founded. We investigated the upscaling of these estimations to a several thousands hectare area using understorey cover measurements done along a regular spatial grid. The only significant correlation linked one satellite vegetation index to understorey biomass.

- We successfully developed empirical relationships to estimate the understorey biomass at the stand level. Further investigations could focus on the analysis of understorey variability over a finer space grid and the potential use of satellite vegetation indexes.
\end{abstract}

Résumé - Estimation de la biomasse aérienne du sous-bois de peuplements de pin maritime à l'aide de mesures de recouvrement.

- Le sous-bois est un compartiment non négligeable dans les études de stocks et de flux des forêts ; cependant il est encore mal quantifié. Les objectifs de notre étude étaient d'établir des relations permettant d'estimer la biomasse du sous-bois de peuplements et d'analyser les possibilités d'extrapolation à l'échelle du massif.

- Des mesures de biomasse aérienne de sous-bois ont été réalisées sur une série de peuplements de pin maritime en Landes mésohygrophile, mésophile et sèche dans le Sud-Ouest de la France.

- Nous avons estimé le stock moyen de biomasse dans ce compartiment à $3.50 \mathrm{t} \mathrm{MS} \mathrm{ha}{ }^{-1}$. Le groupe d'espèces le plus abondant diffère selon le type de landes : herbacées $(23.3 \%)$, fougères $(59.2 \%)$ et mousses $(31.6 \%)$ en landes mésohygrophile, mésophile et sèche, respectivement. Pour chaque groupe d'espèces, des relations significatives ont été mises en évidence entre un indice volumique et la biomasse de sous-bois. Aucune relation n'a été mise en évidence entre les caractéristiques du peuplement et la biomasse du sous-bois. Nous avons envisagé le calcul à l'échelle d'une zone atelier de plusieurs milliers d'hectares en utilisant une grille spatialisée de relevés de recouvrements. Seul un indice satellite de végétation a présenté une corrélation positive avec la biomasse du sous-bois. - Les relations que nous avons développées permettent d'estimer la biomasse du sous-bois à l'échelle du peuplement. L'analyse spatiale à une échelle plus fine et l'utilisation d'un indice de végétation pourraient être des pistes à explorer.

\footnotetext{
* Corresponding author: annabel.porte@ pierroton.inra.fr
} 


\section{INTRODUCTION}

Forest stand management implies the insuring of social, economic and ecological functions, for present and future times. During ministerial conferences on the protection of forests in Europe, six criteria have been presented to be used as indicators of sustainable management (Improved PanEuropean Indicators, 2003). Criterion 1.4 refers to the preservation and improvement of forest contribution to carbon stocking in vegetation and soil and directly requires estimates of understorey amounts as part as the ecosystem biomass. Criterion 2.1 is related to the maintenance of forest health and assessment of the damages in forest and requires quantitative knowledge of the ecosystem vegetation together with insect damages monitoring to build risk indicators.

Carbon flux measurements over European forest ecosystems (Aubinet et al., 2000; Magnani et al., 2007) recently underlined the high intra and between stands variability in carbon balance. Delzon et al. (2003) emphasized the role of the understorey compartment in a Maritime pine stand indicating that its removal would reduce the ecosystem carbon fluxes by $15 \%$. However, understorey contribution to forest carbon stocks and fluxes are often investigated using rough approaches based on biomass to soil surface relationships (Clary and Tiedemann, 1986; Law et al., 2001; Martin et al., 2005; Sebei et al., 2001), for example. In term of carbon stock in French forests, understorey (living biomass+dead-wood) averaged $4 \%$ of total stock, which corresponded for Southern France Maritime pine (Pinus pinaster) plantations to an average of $5 \mathrm{t} \mathrm{DM} \mathrm{ha}^{-1}$ (Dupouey et al., 2000). Recently, fine root biomass was investigated on both tree and understorey compartments indicating a 70\% contribution of non-tree species to fine root biomass (Bakker et al., 2006) in adult Maritime pine stands. However, variability according to species and site conditions are still incomplete in this area where the few prior studies essentially focused on species-specific developmental characterisation of Molinia coerulea (Bergeret, 1980; Delzon, 2000; Lemoine et al., 1983) or Ulex sp. (Augusto et al., 2005).

In the same way, studies aiming at establishing models of ground vegetation biomass were not numerous and partly inaccessible as a result of their being published in native languages or grey literature. Published works all consisted of individualbased allometric relationships between grasses cover, diameter, height or individual volume of shrubs and their corresponding biomass (Alaback, 1986; Andariese and Covington, 1986; Armand et al., 1993; Byrne and Wentworth, 1988; Paton et al., 2002; Smith and Brand, 1983). To develop methods to accurately and simply estimate vegetation stocks in Maritime pine stands, we proposed to use an analogous but area-based approach, linking volume $\left(\mathrm{m}^{3} \mathrm{ha}^{-1}\right)$ per group of species to biomass $\left(\mathrm{g} \mathrm{m}^{-2}\right)$.

The first objective of this paper was to present our results on quantitative estimations of understorey of Maritime pine stands and models that we established to estimate understorey biomass using vegetation cover measurements. The second objective was to investigate methodologies to upscale understorey biomass estimates on large forested areas, through the analysis of understorey spatial cover variability.

\section{MATERIALS AND METHODS}

\subsection{Growing conditions}

Studies were carried out in the "Landes de Gascogne" forest in south-western France (Fig. 1). The 1.06 million hectare forest is mainly constituted of Maritime pine plantations (834000 ha, IFN, 2006). The area is characterised by a temperate maritime climate with cool wet winters and warm dry summers. Over the period 1950-2000, mean annual temperature was $13.0^{\circ} \mathrm{C}$, with average minimum and maximum temperatures of $2.3{ }^{\circ} \mathrm{C}$ and $9.5^{\circ} \mathrm{C}$ in January, and $14.6{ }^{\circ} \mathrm{C}$ and $26.0^{\circ} \mathrm{C}$ in July. Mean annual precipitations (1970-2000) were $977 \mathrm{~mm}$. The soil is a sandy hydromorphic humic podzol with a cemented Bh horizon (alios) limiting the root zone depth to $-0.8 \mathrm{~m}$, low soil phosphorus and nitrogen levels and mean $\mathrm{pH}$ of 4.0. Soil texture analysis shows the soil is $90 \%$ sand, $5 \%$ silt and $5 \%$ clay (Augusto et al., 2006; Delzon et al., 2005). The area is commonly divided in site classes according to soil water and nutrient availability: humid moor-lands (very rare), mesohygric moorlands (MH), mesic moorlands (M), mesoxeric moorlands, dry moorlands (D) and coastal dunes (Timbal and Caze, 2003).

\subsection{Methods for establishment of biomass relationships}

In July 2005, fourteen Maritime pine stands (Fig. 1) were sampled for understorey biomass measurements, according to their a-priori position in this typology, excluding the sandy dune area. They were of equivalent tree age ( 25 to 35 year-old), covering a minimum area of 4 ha to allow measurements in a homogeneous $100 \mathrm{~m}^{2}$ plot. Most stands had been monitored for the last 10 years in term of tree diameter and height. Main stand characteristics are presented in Table I.

In each stand, a $15 \mathrm{~m}$ radius circular plot (circa $700 \mathrm{~m}^{2}$ ) positioned in a homogeneous part of the stand was used for determination of floristic composition. All phanerogam species (maximum height $2 \mathrm{~m}$ ), pteridophytes and bryophytes growing on soil were taken into account. Absolute cover was provided for each species, separating woody species, herbaceous species, bracken fern and mosses. For each group, absolute cover was expressed using two scales, a classical 5 class Braun-Blanquet notation (Maarel, 2005) or a more detailed 11 class notation. In the French National Forest Inventory (IFN, 2007), the Braun-Blanquet notations accounted for $0-5 \%$ cover, the second $5-25 \%$ and the last three to $25-50 \%, 50-75 \%$ and $75-100 \%$ respectively. The detailed notations used a first and 11th class that accounted for $0-5 \%$ cover and $95-100 \%$ cover, respectively, whereas all intermediate classes were $10 \%$ large classes. On each stand, for each species, average height was visually estimated, by reference to a $2 \mathrm{~m}$ high pole.

Aerial biomass was sampled on $20\left(1 \times 1 \mathrm{~m}^{2}\right)$ quadrats randomly located in a 1 ha plot (56.4 m radius) centred on the previous $15 \mathrm{~m}$ radius circle. All plants inside the quadrat were cut at soil level and gathered per species group (woody sp., herbaceous sp., bracken, mosses). They were oven-dried $\left(65^{\circ} \mathrm{C}\right)$ until constant weight was reached and weighted. Results were then expressed in tons of dry matter per hectare $\left(\mathrm{t} \mathrm{DM} \mathrm{ha}^{-1}\right)$.

\subsection{Methods for upscaling at the regional level}

Between June and August 2005, a network of 145 stands (grid step $=2 \mathrm{~km}$ ) was settled in a 32692 ha area close to Pontenx-lesForges (Fig. 1, Tab. I) to monitor forest health at the landscape scale 


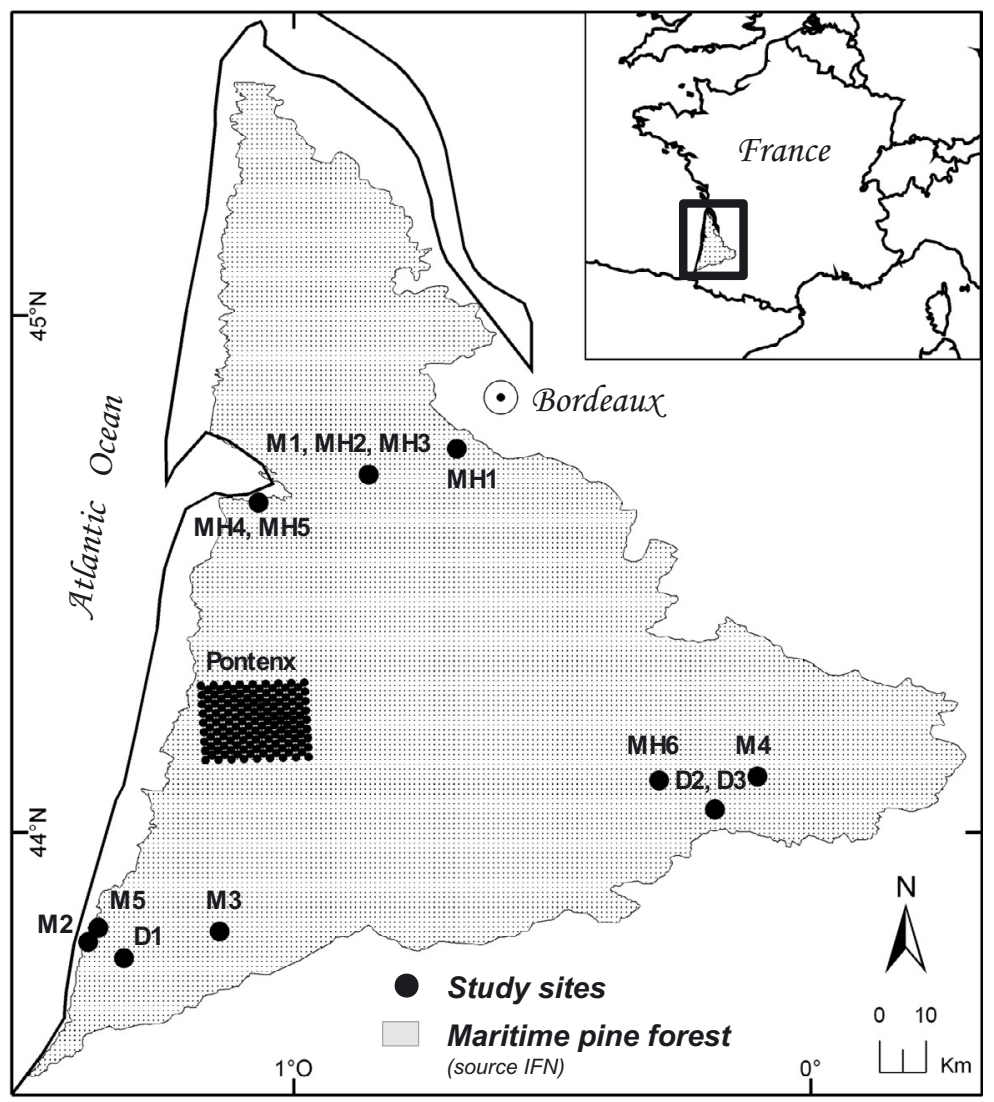

Figure 1. Map of the study area close to Bordeaux, in the South-West French Maritime pine plantation forest. Black points, together with the site codes, represent the locations of the sites sampled for establishing the allometric relationships. The black rectangular area named "Pontenx" indicates the area used for the up-scaling trial.

as part as a pilot zone to study sustainable management in Atlantic forests (Poissonnet et al., 2007). In this study, it was used to study upscaling of biomass estimates. Using the French NFI data (tree, understorey and soil), a mapping of the whole Pontenx forested area provided us with the percentage area per moorland type (IFN, 2007). On the 32692 ha of the Pontenx area, 27242 ha were Maritime pine stands, with 7 778, 17134 and 2330 ha in mesohygric, mesic and dry moorlands, respectively.

Absolute cover of each vascular plant species was expressed using the classical Braun-Blanquet notation on a $400 \mathrm{~m}^{2}$ zone per stand, according to the French NFI protocol (IFN, 2007). Stands characteristics were noted: tree age, tree density, maritime pine wood productivity class, occurrence of recent silvicultural practices (thinning, pruning or understorey cleaning). Inside each stand, the presence of a sandy cemented $\mathrm{Bh}$ horizon was looked for by digging down to $1.20 \mathrm{~m}$ depth and depth of the nearest ditch outside the stand was measured.

NDVI (Near Infrared Vegetation Index) was calculated on each 145 grid point using a satellite image (SPOT5, 13th July, 2005). The SPOT image pixel corresponded to a $10 \times 10 \mathrm{~m}^{2}$ square, and NDVI was calculated as the average value over 9 pixels centred on each grid point, as follows:

$$
N D V I=\frac{\sum_{p=1}^{9} \frac{N I R-R E D}{N I R+R E D}_{p}}{9}
$$

where RED and NIR stand for the spectral reflectance in the red (XS2 canal) and near-infrared (XS3 canal) regions, respectively.

\subsection{Analysis}

In order to evaluate understorey biomass stocks on Maritime pine forests, we fitted relationships between the biomass per species group and their phytovolume (Vol, $\mathrm{m}^{3} \mathrm{ha}^{1}$ ) which was calculated according to:

$$
V o l_{\text {speciesgroup }}=\sum_{\text {species }} \frac{\text { Cover }_{\text {species }}}{100} 10000 \text { Height }_{\text {species }}
$$

with Cover per species expressed in $\%$ and Height in meters. Through the text, indexes 5 and 11 will refer to volumes estimated using cover measurements done using the 5 and 11 cover class methodologies. Allometric models were fitted between biomass and volume and/or volume $^{2}$ using non linear procedures.

Statistical analysis (ANOVA F, Pearson correlations $t$ test) and fittings (Non linear least square procedures) were done using the SYSTAT software (v 10, SPSS Inc. 2000). The significance level was provided by test probabilities ( $p$ value). Non linear and linear regressions were tested to establish relationships between biomass and phytovolume. Best models were selected according to the significant level of the explicative variables, the residual mean squares values (RMS) of the models and the analysis of modelled versus measured plots 
Table I. Main stand characteristics. Classification of moorland types was assessed using the vegetation measurements according to Timbal and Caze (2005). MH, M and D stand for mesohygric, mesic and dry moorlands, respectively.

\begin{tabular}{llccc}
\hline $\begin{array}{l}\text { Stand } \\
\text { code }\end{array}$ & Pine forest & $\begin{array}{c}\text { Stand } \\
\text { age } \\
(\text { year })\end{array}$ & $\begin{array}{c}\text { Stand } \\
\text { BA } \\
\left(\mathrm{m}^{2} \mathrm{ha}^{-1}\right)\end{array}$ & $\begin{array}{c}\text { Stand } \\
\text { density } \\
(\text { tree ha }\end{array}$ \\
\hline MH1 & Cestas Bray & 34 & 28.2 & 313 \\
MH2 & Marcheprime C5 & 32 & 27.8 & 414 \\
MH3 & Marcheprime H5 & 35 & 20.3 & 294 \\
MH4 & Gujan-Mestras & 31 & 22 & 229 \\
& Nezzer 1262 & & & \\
MH5 & Gujan-Mestras & 33 & 28.8 & 273 \\
& Nezzer 590 & & & \\
MH6 & Retjons 30 & 28 & 22.2 & 356 \\
M1 & Marcheprime C21 & 30 & 15.6 & 239 \\
M2 & Vieux Boucau 2 & 32 & 31.9 & 391 \\
M3 & Herm 49 & 27 & 22.5 & 347 \\
M4 & Losse 41 & 28 & 25.6 & 306 \\
M5 & Messanges 23 & 31 & 31.4 & 419 \\
D1 & Soustons 42 & 31 & 16.9 & 536 \\
D2 & Vielle Soubiran 1 & 28 & 22.3 & 434 \\
D3 & Vielle Soubiran 2 & 25 & 20.9 & 584 \\
& Pontenx les forges & $4-61$ & 1 & $113-2500$ \\
\hline
\end{tabular}

and residual plots. Principal component analysis (PCA) and factorial correspondence analysis (FCA) were performed using the ADE4 package (Chessel et al., 2004) of the R freeware (R Development Core Team, 2007). Spatial correlations were investigated using semivariograms and Moran I tests (R Development Core Team, 2007).

\section{RESULTS}

\subsection{Understorey above-ground biomass}

Total understorey aboveground biomass per site ranged between $1.5 \mathrm{tDM} \mathrm{ha}^{-1}$ and $8.2 \mathrm{tDM} \mathrm{ha}^{-1}$ according to the stand. In Figure 1, sites were presented from left to right according to their moorland type, from mesohygric to dry ones. This classification was assessed using the vegetation communities composition and indicator species criteria established by Timbal and Caze (Timbal and Caze, 2003). The total mean biomass reached $3.5 \mathrm{t} \mathrm{DM} \mathrm{ha}^{-1}$; dry moorland presented the highest understorey biomass with an average of $5.56 \mathrm{t} \mathrm{DM} \mathrm{ha}^{-1}$,Tab. II) over the three sampled sites. A large variability existed among each moorland type in the understorey biomass; indeed standard deviation could be of the same magnitude as the mean biomass values itself, according to the species group (Tab. II). Herbaceous species, mostly consisting in Molinia coerulea, accounted in average for $12.6 \%$ (min-max $0.10-24.4 \%$ ) and $23.3 \%$ of total biomass for mesic and mesohygric sites, respectively. In dry moorlands, herbaceous species accounted only for $0.15 \%$ (min-max $0-0.42 \%$ ) of total biomass. Bracken was found in all moorland types, but accounted for the largest
Table II. Mean values and standard deviation of understorey biomass $\left(\mathrm{t} \mathrm{DM} \mathrm{ha}^{-1}\right.$ ) per moorland type and group of species. Total understorey biomass was expressed in dry matter per hectare (t DM. ha ${ }^{-1}$ ) $\mathrm{MH}=$ mesohygric, $\mathrm{M}=$ mesic, $\mathrm{D}=$ dry moorlands.

\begin{tabular}{|c|c|c|c|c|c|}
\hline \multirow{2}{*}{$\begin{array}{l}\text { Stand } \\
\text { code }\end{array}$} & \multicolumn{4}{|c|}{ Biomass (t DM ha ${ }^{-1}$ ) } & \multirow{2}{*}{$\frac{\mathrm{t} \mathrm{DM} \mathrm{ha}^{-}}{\text {Total }}$} \\
\hline & Bracken & $\begin{array}{c}\text { Herbaceous } \\
\text { sp. }\end{array}$ & $\begin{array}{c}\text { Woody } \\
\text { sp. }\end{array}$ & Mosses & \\
\hline \multirow[t]{2}{*}{ MH } & 0.1477 & 0.6821 & 1.5844 & 0.8699 & 3.2841 \\
\hline & $(0.2417)$ & $(0.2012)$ & $(0.9194)$ & $(0.5825)$ & $(1.2240)$ \\
\hline \multirow[t]{2}{*}{ M } & 1.4269 & 0.2877 & 0.2587 & 0.6083 & 2.5816 \\
\hline & $(0.3821)$ & $(0.2526)$ & $(0.2373)$ & $(0.9442)$ & $(0.8292)$ \\
\hline \multirow[t]{2}{*}{$\mathrm{D}$} & 0.2029 & 0.0005 & 1.7288 & 3.6227 & 5.5549 \\
\hline & $(0.2511)$ & $(0.0079)$ & (1.2234) & $(1.5962)$ & $(2.4868)$ \\
\hline
\end{tabular}

biomass in mesic moorlands $(59.2 \%$ of total biomass, min$\max 27.7-82.4 \%$ ). Mosses turned out to be a large biomass compartment, reaching in average $31.6 \%$ of total biomass $(S D=25 \%)$. This species group formed the largest part of the biomass in dry moorland sites, representing 56.7, 77.0 and $61.2 \%$ on D1, D2 and D3 sites, respectively.

\subsection{Estimating understorey aboveground biomass using phytovolume}

We established significant relationships between biomass and phytovolume per species group (Fig. 3, Tab. III). For bracken, mosses and herbaceous species, the shape of the relationships involved using a square power on volume, whereas we established a linear relationship for woody species. The latter relation was the less satisfying one (Tab. III). Outliers corresponded (i) to a dry moorland stand (D3 characterised by a high dominance of Calluna vulgaris in the woody compartment corresponding to a low understorey volume and a high biomass, and (ii) to a mesohygric moorland stand (MH2) presenting a large amount of high shrubs (Frangula alnus, Erica scoparia) and tree seedlings (Pinus pinaster, Quercus robur), resulting in a large volume and low biomass.

As indicated by models analysis using residual plots, fitted versus measured plots and residual mean square values (Tab. III), goodness of fit was most of the time better when using volumes estimated using the 11 classes method rather than the classical Braun-Blanquet 5 classes method. Using only cover measurements instead of volume did not allow correct relationships to estimate biomass per species group to be attained (data not shown).

\subsection{Variability of understorey vegetal communities}

We looked at the distribution of the 14 sampled sites according to their biomass per species group (Fig. 4A). Axis 1, accounting for $50.5 \%$ of total inertia, discriminated sites according to the amount of herbaceous biomass (component loading 0.88$)$, whereas axis 2 (37.1\% of total inertia) discriminated sites according to the amount of woody species 


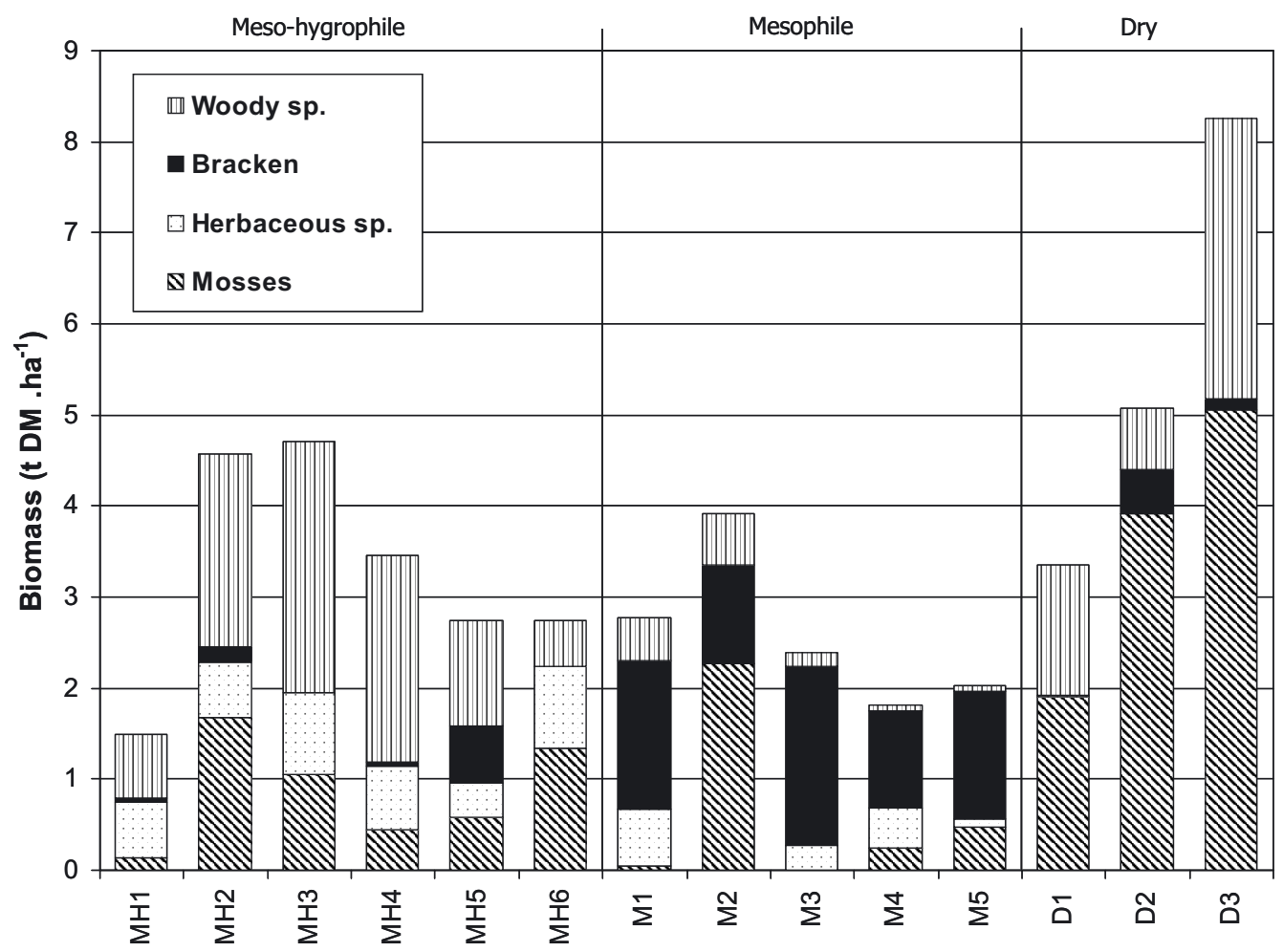

Figure 2. Biomass $\left(\mathrm{t} \mathrm{DM} \mathrm{ha}^{-1}\right)$ per species group, for each sampled site. Slashed bars = mosses, Dotted bars = herbaceous species, Full bars = bracken, Horizontal bars = woody species. Sites are ordered according to their moorland type: mesohygric, mesic and dry moorlands according to the classification by Timbal and Caze (2005).
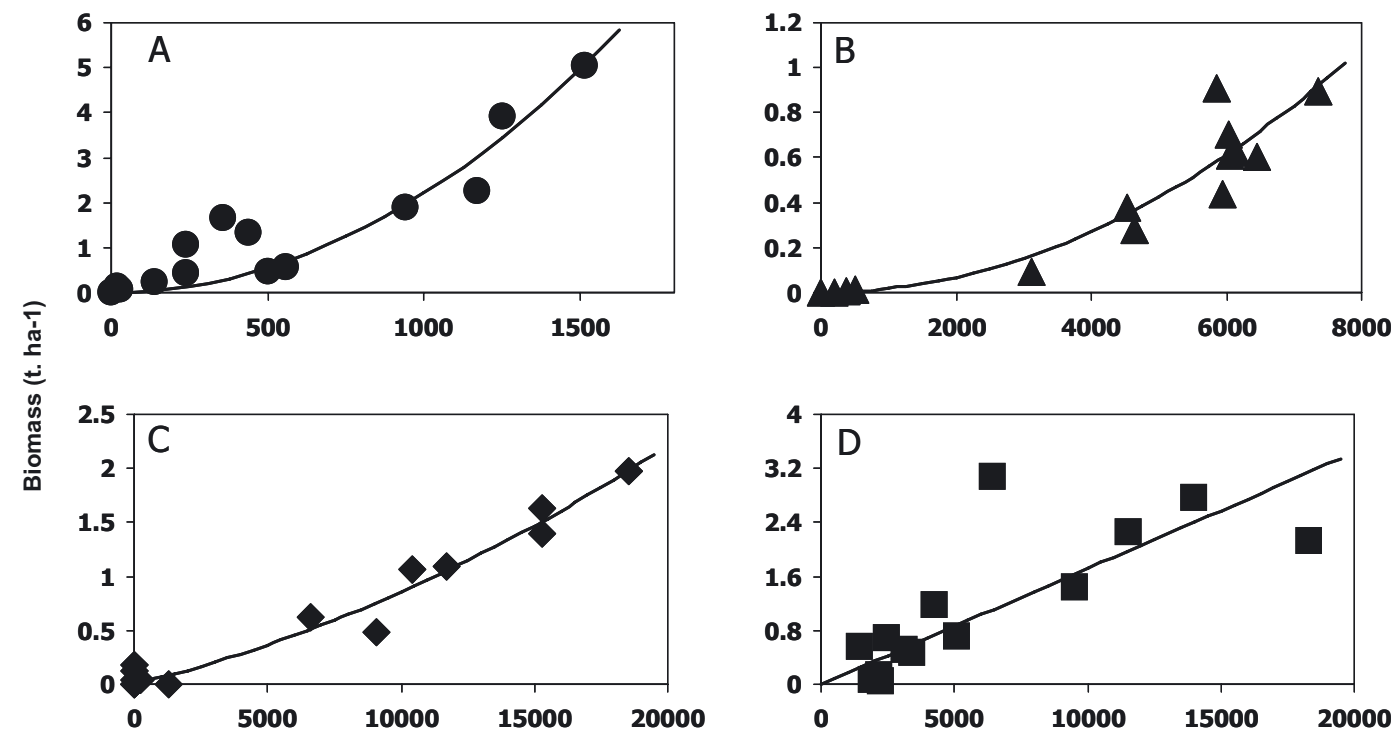

Phytovolume $\left(\mathrm{m}^{3} \mathrm{ha}^{-1}\right)$

Figure 3. Relationship between the biomass $\left(\mathrm{t} \mathrm{DM} \mathrm{ha} \mathrm{h}^{-1}\right)$ and the phytovolume $\left(\mathrm{m}^{3} \mathrm{ha}^{-1}\right)$. Each point corresponds to the stand estimate per species group (A) Mosses (B) Herbaceous species (C) Bracken (D) Woody species. The full lines present the models based on the 11 class measurements (Tab. II). 
Table III. Models and parameters to estimate understorey biomass per species group ( $\mathrm{t}$ MS/ ha) as a function of their phytovolume (m3). Indexes 5 and 11 refer to the estimation of phytovolume using the Braun-Blanquet cover measurements and the 11 class cover measurements, respectively.

\begin{tabular}{lllll}
\hline Species group & Model & RMS & a1 & a2 \\
\hline Mosses* & $\mathrm{a} 1 . \mathrm{Vol}_{11}^{2}$ & 0.351 & $2.210^{\mathrm{E}}-6\left(1.825^{\mathrm{E}}-7\right)$ & $/$ \\
Mosses & $\mathrm{a} 1 . \mathrm{Vol}_{5}^{2}$ & 0.398 & $2.086^{\mathrm{E}}-6\left(1.845^{\mathrm{E}}-7\right)$ & $/$ \\
Herbaceous sp.* & $\mathrm{a} 1 . \mathrm{Vol}_{11}^{2}$ & 0.013 & $1.697^{\mathrm{E}}-8\left(1.028^{\mathrm{E}}-9\right)$ & $/$ \\
Herbaceous sp. & $\mathrm{a} 1 . \mathrm{Vol}_{5}^{2}$ & 0.023 & $1.966^{\mathrm{E}}-8\left(1.619^{\mathrm{E}}-9\right)$ & $/$ \\
Bracken* & $\mathrm{a} 1 . \mathrm{Vol}_{5}^{2}+\mathrm{a} 2 . \mathrm{Vol}_{5}$ & 0.012 & $4.511^{\mathrm{E}}-9\left(1.132^{\mathrm{E}}-9\right)$ & $3.897^{\mathrm{E}}-5\left(1.584^{\mathrm{E}}-5\right)$ \\
Bracken* & $\mathrm{a} 1 . \mathrm{Vol}_{11}^{2}+\mathrm{a} 2 . \mathrm{Vol}_{11}$ & 0.017 & $2.494^{\mathrm{E}}-9\left(1.082^{\mathrm{E}}-9\right)$ & $6.061^{\mathrm{E}}-5\left(1.624^{\mathrm{E}}-5\right)$ \\
Woody sp.* & $\mathrm{a} 1 . \mathrm{Vol}_{11}$ & 0.445 & $1.716^{\mathrm{E}}-4\left(2.244^{\mathrm{E}}-5\right)$ & $/$ \\
Woody sp. & $\mathrm{a} 1 . \mathrm{Vol}_{5}$ & 0.518 & $1.567^{\mathrm{E}}-4\left(2.080^{\mathrm{E}}-5\right)$ & $/$ \\
\hline
\end{tabular}

* Indicates the best fitting for each species group, according to residual mean squares values (RMS) and analysis of modelled versus measured plots and residual plots. Values in parenthesis are asymptotic standard deviation on estimated values.

\section{A: Correlation circle}

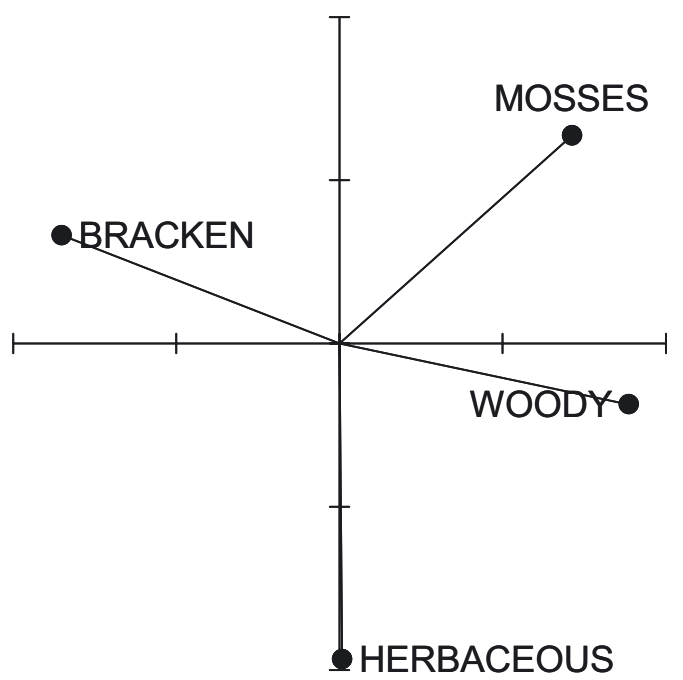

\section{B: Stands distribution}

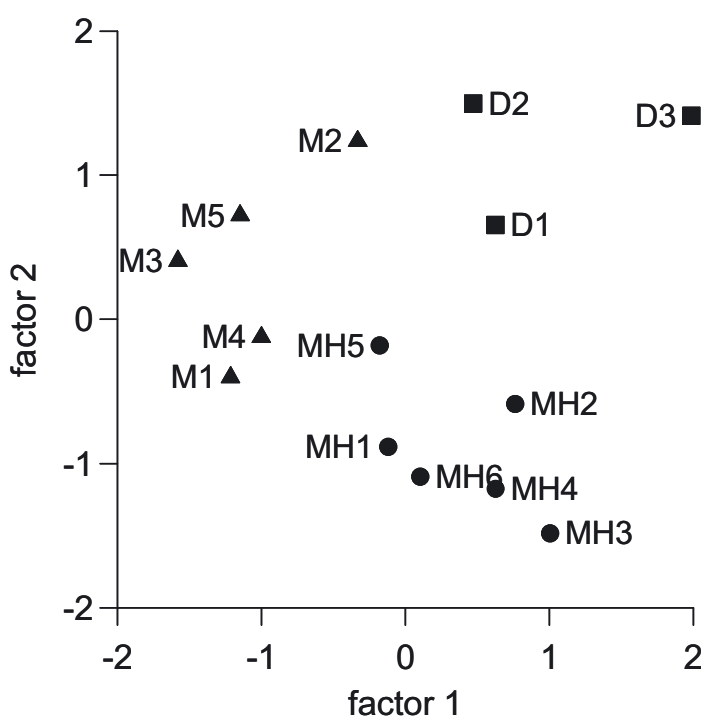

Figure 4. Principal component analysis using the biomass data per species group for the 14 sampled sites. (A) Correlation circle for axes 1 and 2, accounting for 50.4 and $37.1 \%$ of the total inertia. (B) Projection of the sampled sites upon the factorial plane 1-2. (•) Mesohygric moorland sites, $(\mathbf{\Lambda})$ mesic sites, $(\mathbf{\square})$ dry moorland sites.

on one end and bracken on the other end. Large amounts of mosses were associated with low herbaceous biomasses. Site projection underlined the specificity of dry moorland sites, characterised by large amounts of moss biomass (Fig. 4B). Mesohygric sites all demonstrated large herbaceous biomass but the group of sites was also spread out along the second axis, according to the relative biomass of bracken and woody species. On the left end of the graph (Fig. 4B) were gathered the bracken - abundant mesic sites.

Figure 5A presents the projection of the 145 Pontenx sites. Site grouping was done using abundance classes per species. Dry moorlands were characterised by large amounts of $\mathrm{Hal}$ imium alyssoides, Erica cinerea and Calluna vulgaris, mesic sites by abundance of Pteridium aquilinum and mesohygric sites by abundance of Molinia coerulea, Erica tetralix, E. scoparia and E. ciliaris (Fig. 5B). A group of 10 maritime pine stands presented an off-centred position on the right side of the graph. Their vegetation was characterised by abundance of broadleaved trees (Acer negundo, Castanea sativa), open area species (and they were either located on riparian areas or abandoned agricultural fields (presence of Phytolacca americana, species enhanced on rich and disturbed areas). The 14 biomass sampling sites were added as additional data; their projection using abundance data resulted in the same grouping than using biomass per species group (Fig. 4) except for the MH5 site. The latter was characterised by species abundances similar to 


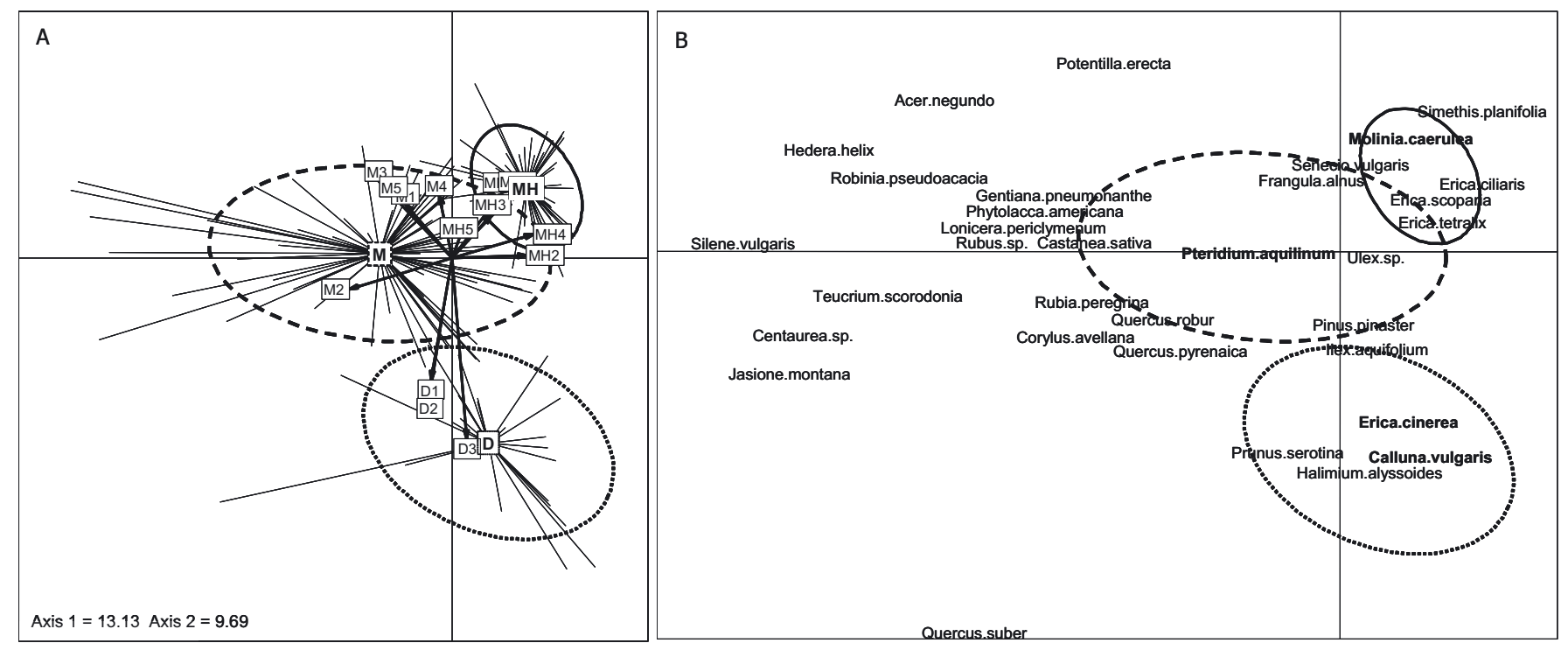

Figure 5. Factorial correspondence analysis using the abundance notations per species for the Pontenx 145 sites. (A) Projection of the sites upon the factorial plane 1-2 (accounting for 13.13 and $9.69 \%$ of the total inertia). (-) MH mesohygric moorland sites, (- -) M mesic sites, (...) D dry moorland sites. Biomass sampling sites projected as additional data are presented using their stand code. (B) Projection of the species.

mesohygric sites except for abundant bracken; this species was the one that resulted in such a biased classification in the correspondence analysis.

\subsection{Investigating upscaling of understorey biomass at the regional scale}

Using the volume per species and biomass equations presented in Table III, we estimated biomass over the 145 grid points and looked at their spatial structure. Figure 6 presents the map of the Pontenx area, each grid point being represented proportional to the estimated understorey biomass (bracken+herbaceous sp.+woody sp.). Biomass estimates averaged $1.3 \mathrm{t} \mathrm{DM} \mathrm{ha}^{-1}(S D=0.81)$ and were varying between 0.15 and $4.3 \mathrm{t} \mathrm{DM} \mathrm{ha}^{-1}$. Biomass per moorland type was significantly different (ANOVA, $p=9.6 \mathrm{E}^{-7}$ ); understorey biomass in mesic stands equalled 1.7 that in mesohygric or dry stands. They demonstrated no spatial pattern that could allow interpolation between sampling points, as confirmed by a flat semi-variogram analysis and a non significative Moran I at all space steps.

We found no significant relationships using the 145 biomass estimates (data not shown) between the understorey biomass estimates and the Pontenx Maritime pine ecosystem characteristics such as tree age, tree density, maritime pine wood productivity class, cemented Bh horizon depth, nearest ditch depth and occurrence of recent silvicultural practices (thinning, pruning or understorey cleaning). Recent silvicultural practices seemed to indeed reduce understorey biomass, but the large variability didn't allow showing any significant effect of forest management. The only significant correlation linked vegetation NDVI indexes and total biomass $(r=0.49$, $\left.p=3.8 \mathrm{E}^{-10}\right)$; it was mostly due to bracken biomass variations as indicated by the high correlation coefficient $(r=0.65$, $\left.p=6 \mathrm{E}^{-15}\right)$.

Considering that no spatial pattern was observed and that relationships to stand characteristics remained insignificant, estimating understorey biomass was done using forest areas and average biomass per moorland type. On the 32692 ha of the Pontenx area, 27242 ha were Maritime pine stands, with $28.5,61.9$ and $8.5 \%$ in mesohygric, mesic and dry moorlands, respectively. Biomass stocks were estimated to $17.476,1.921$ and $18.350 \mathrm{Mt}$ on the whole area, for bracken, herbaceous and woody species, respectively.

\section{DISCUSSION}

Studying biomass per moorland type widened our knowledge of the variability of the understorey compartment in the Landes de Gascogne Maritime pine forest; indeed past studies focused essentially on mesohygric moorlands and mostly paid attention to the dominant species, Molinia coerulea (Bergeret, 1980; Delzon, 2000; Lemoine et al., 1983). The understorey stock value measured in these plantations were in the lower range encountered in various temperate forests where understorey stocks ranged between a few kilograms and $40 \mathrm{t} \mathrm{DM} \mathrm{ha}^{-1}$ (Clary and Tiedemann, 1986; Etienne et al., 1991; Lakida et al., 1996; Lin et al., 2003). However they fitted the same range as in previous studies in mesohygric Maritime pine stands (Bergeret, 1980; Delzon, 2000). Our study underlined the importance of moss contribution to understorey biomass. Few studies integrated mosses in temperate forest areas (contrary to boreal forests), when studying forest functioning or quantifying biomass stocks. It was found to 


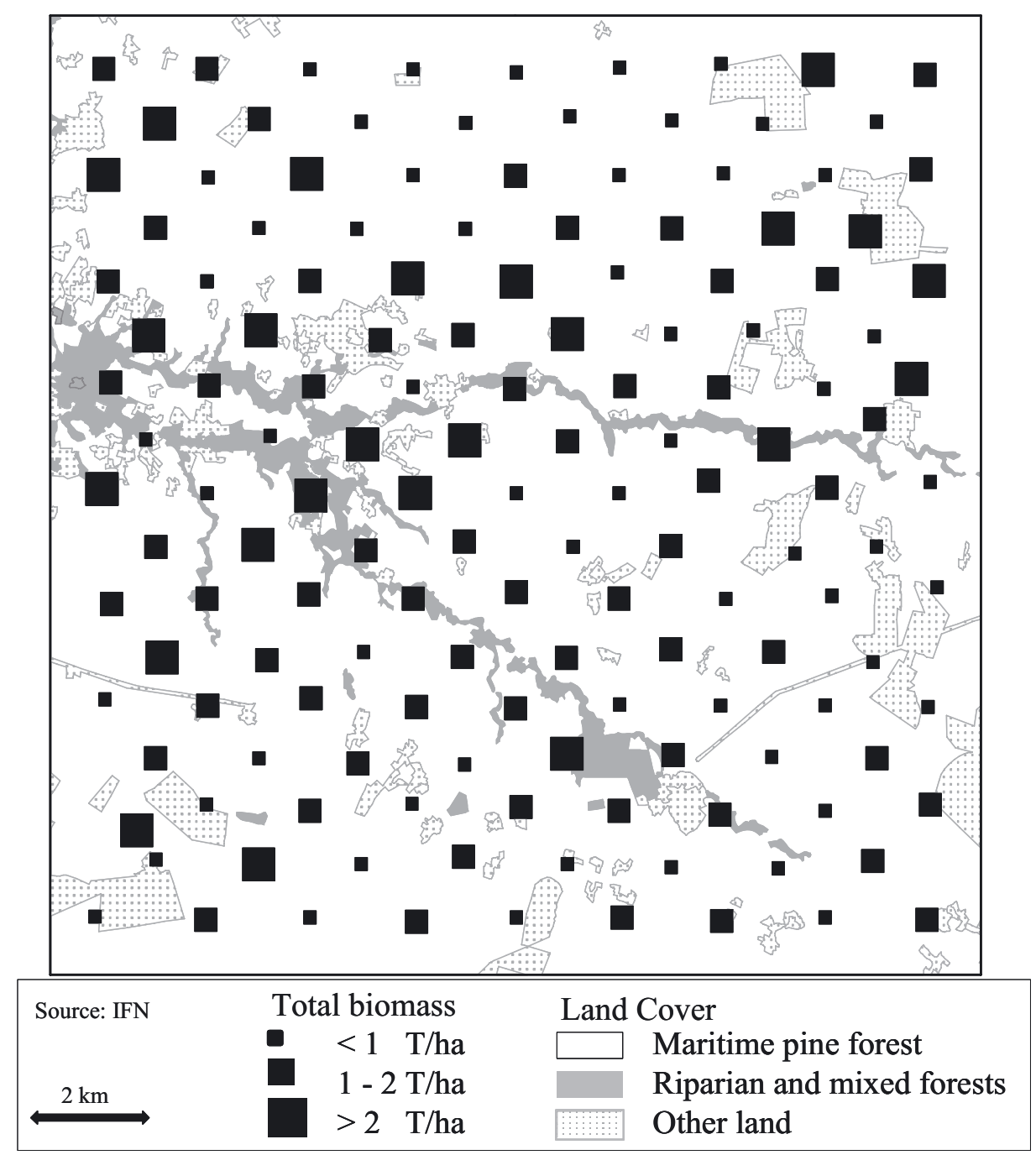

Figure 6. Map of the Pontenx zone figuring the total understorey biomass estimates on the 145 point spatial grid. Square sizes are proportional to biomass values. Mosses were not included in these biomass values.

vary considerably and accounted for 13 to $85 \%$ of understorey biomass (Den Ouden and Alaback, 1996; Kubicek and Jurko, 1975; Popiolek, 1978; Telfer, 1972; Tremblay and Larocque, 2001). At the northern limits of temperate zones, it was indeed found to account for $25 \%$ of understorey biomass in a temperate Tsuga heterophylla/ Picea sitchensis forest in Alaska (Den Ouden and Alaback, 1996). Moreover, mosses could contain high nutrient contents (Binkley and Graham, 1981; Tremblay and Larocque, 2001). In southern France Maritime pine plantations, soils are nutrient poor podzols and stands are intensively managed over short rotations for wood production. As a consequence, regarding the evaluation of forest sustainable management, mosses could end up to be a significant compartment to investigate in relation to the elevated biomass they represent in the understorey (10 to $77 \%$ in our sampling) and also to their potential role in the ecosystem nutrient cycle.

The allometric relationships that we established between volume and biomass per species group provided very satisfying models to estimate understorey biomass, except for the woody species group. On the one hand, high shrubs ( $>2-3 \mathrm{~m}$ ) and small trees (up to $10 \mathrm{~m}$ understorey broadleaved trees) were ignored in this study; our methodology was actually unsuitable to undertake the sampling of sparse individuals. Moreover, woody species group presented a larger variability in species richness (average $S=7.3$ species per site) than the other species group $(S=1,3.1$ and 1.8 species per site for bracken, herbaceous species and mosses respectively). This variability coincided with differences in architecture and development of the woody species (Erica sp., Ulex sp., Quercus sp., Rubus sp., etc.); that probably induced species-specific relationships between volume and biomass and explained the lower quality of the overall fitting (Fig. 3D).

Shrub biomass was generally estimated with allometric equations using individual diameter or height (Alaback, 1986; Augusto et al., 2005; Lin et al., 2003; Paton et al., 2002; Smith and Brand, 1983) mimicking the approach highly developed for trees (see reviews by (Ter Mikaelian and Korzukhin, 1997; Zianis and Mencuccini, 2003; Zianis et al., 2006). On the other 
hand, biomass of herbaceous species and mosses were often estimated using regressions with ecological cover notations (Alaback, 1986; Andariese and Covington, 1986; Muukkonen et al., 2006; Yarie and Mead, 1988). We combined both approaches using vegetation cover notations and species-specific heights; our aim at testing such a method was to establish accurate biomass models that also presented the convenient advantage of permitting quicker field sampling than individual biomass measurements. Volume occupied by plants (vegetation cover $x$ height) rather than cover or individual dimensions was already considered as an efficient estimator of plant biomass in studies investigating either biomass dynamics over large land areas (Byrne and Wentworth, 1988) or forest fuel load (Armand et al., 1993; Byrne and Wentworth, 1988; Fernandes et al., 2002; Kazanis et al., 2006).

Our concern was to provide accurate and easy to apply methods to quantify understorey biomass, therefore we compared two vegetation cover notations. The use of a detailed (11) cover class vegetation method resulted in better models than using a classical Braun-Blanquet method (Tab. III). Up to date, French National Inventories are using the classical method and are not indicating the average height of the species. However, to dispose of accurate indicators of understorey biomass stocks in the Landes de Gascogne forests using our volume/biomass models, we recommend that future inventories include height estimates combined to the 11 class cover measurements.

The PCA and FCA both succeeded in segregating the biomass sampled sites according to their moorland types. The FCA segregated the 145 sites according to cover but when based on biomass per species group, it was not conclusive because we lacked information on moss biomass. The discrimination between bracken and woody species on the PCA first axis probably reflected understorey disturbances consequent to forest management practices. Timbal and Caze (2003) indicated that moorlands with large amounts of Pteridium aquilinum (referred to as mesic) were not corresponding to a true vegetation facies but rather to a degradation of mesohygric moorland resulting from human action. This phenomenon was empirically known to forest managers: bracken (Pteridium aquilinum) high development followed understorey cleanings and they could notice its progressive reduction with time, together with a larger development of woody species (Demounem and Legigan, 1988; Saint-Didier, 1977a) Studies on bracken indeed underlined the role of disturbance in its dynamics; it favours the development of bracken dormant buds directly through rhizome fragmentation (Den Ouden, 2000) or indirectly by removing woody species and herbaceous competition(McDonald et al., 2003).

The PCA second axis opposed sites with abundant herbaceous species with sites with abundant mosses. It can be interpreted as a humidity gradient. Molinia coerulea was classically known to be indicating humid moorland conditions (Guinaudeau, 1964; Rameau et al., 1989; Saint-Didier, 1977b; Timbal and Caze, 2003) whereas large amounts of moss (Pleurozium schreberi and Dicranum scoparium) had already been observed under drier site conditions (Saint-Didier, 1977b; Timbal and Caze, 2003).
We can conclude from the combination of the PCA and FCA analysis that vegetation cover is a useful indicator to discriminate moorland types, whereas biomass estimates forms a more complex indicator integrating both environmental conditions and management practices.

We didn't find evidence of any relationship between canopy cover or stand characteristics and understorey biomass. Understorey biomass was linked to stand characteristics such as canopy cover (Ford and Newbould, 1977; Muukkonen et al., 2006; Pieper, 1990; Pyke and Zamora, 1982). In maritime Pine stands, cover didn't vary along a large range of values impeding such a clear relationship. Indeed, on the one hand, Maritime pine crown architecture and foliage biomass (Porté et al., 2000) make it a low density foliage species and on the other hand, stand thinnings are frequently carried out to minimise inter-tree competition and consequently homogenise the stand leaf area index (LAI from 1.7 to 2.9, Delzon and Loustau, 2005). A more precise knowledge of nature and dates of management practices could improve the understanding of understorey biomass repartition.

The relationship between understorey biomass and NDVI was due to the abundance of bracken. The NDVI index demonstrates a high sensitivity to the chlorophyll content of the vegetation (Dawson et al., 2003), which could explain its higher correlations with bracken and herbaceous species rather than woody species. In the Landes de Gascogne, the NDVI signal integrated both the coniferous trees and the understorey signal (Duchemin et al., 1999). Therefore before any possible use of this signal to upscale understorey biomass estimate at the regional scale, the analysis of wintertime NDVI indexes could help discriminate the stand from the understorey contributions.

The absence of spatial pattern in the total biomass distribution over the $2 \mathrm{~km}$ grid impeded us from kriging estimates between two consecutive sampling points. This random pattern could be explained by the forest structure at the regional level: it consists of a mosaic of small private parcels, designed to suit intensive forest management practices (cleanings, thinnings, drainage) which recurrently interfere in plant development. The flat semi-variogram indicated no spatial pattern on the $2 \mathrm{~km}$ grid but a spatial pattern could remain at a smaller space step. To deepen the analysis of spatial correlations, cover data from the French National Inventory network, following a $1 \mathrm{~km}$ square grid, could be used.

\section{PERSPECTIVES}

Associating cover measurements to species height estimates allowed us to establish allometric relationships for calculating the biomass of the understorey for each species group (mosses, bracken, herbaceous and woody species). This methodology presents large applications in estimating carbon stocks in forest, vegetation amounts as explicative of animal biodiversity, and also fuel loads in fire risk assessment studies.

Acknowledgements: Authors would like to thanks the many hands that took part in the field samplings and measurements, from the EPHYSE and BIOGECO research units, the IEFC (Institut Européen 
de la Forêt Cultivée), the Hermitage Forest Experimental Unit and French FNI: S. Arigoni, F. Bourrinet, R. Burlett, N. Cheval, T. Compagnon, H. Jaukinen, F. Lagane, C. Lambrot, T. Labbé, D. Loustau, S. Lopez, M. Sartore, V. Savornin, L. Séverin, P. Trichet. Many thanks go to A. Hargraves and M.S. Samalens for the linguistic revision of this manuscript.

This work was funded thanks to the FORSEE project (European Union and FEDER- Interreg IIIB Atlantic Area financings) and the NetForPest project (Forest Focus European Program). The SPOT image was made available thanks to the ISIS Program (SPOT/Programme ISIS, Copyright CNES).

\section{REFERENCES}

Alaback P.B., 1986. Biomass regression equations for understory plants in Coastal Alaska: effects of species and sampling design on estimates. Northwest Sci. 60: 90-103.

Andariese S.W. and Covington W.W., 1986. Biomass estimation for four common grass species in Northen Arizona Ponderosa pine. J. Rangeland Manage. 39: 472-473.

Armand D., Etienne M., Legrand C., Marechal J., and Valette J.C., 1993. Phytovolume, phytomasse et relations structurales chez quelques arbustes méditerranéens. Ann. Sci. For. 50: 79-89.

Aubinet M., Grelle A., Ibrom A., Rannik U., Moncrieff J., Foken T., Kowalski A.S., Martin P.H., Berbigier P., Bernhofer C., Clement R., Elbers J., Granier A., Grunwald T., Morgenstern K., Pilegaard K., Rebmann C., Snijders W., Valentini R., and Vesala T., 2000. Estimates of the annual net carbon and water exchange of forests: the Euroflux methodology. Adv. Ecol. Res. 30: 113-175.

Augusto L., Badeau V., Arrouays D., Trichet P., Flot J.L., Jolivet C., and Merzeau D., 2006. Caractéristiques physicochimiques des sols à l'échelle d'une région naturelle à partir d'une compilation de données. Exemple des sols du massif forestier landais. Etude et gestion des sols 13: 7-22.

Augusto L., Crampon N., Saur E., Bakker M.R., Pellerin S., Lavaissière de C., and Trichet P., 2005. High rates of nitrogen fixation of Ulex species in the understory of maritime pine stands and the potential effect of phosphorus fertilization. Can. J. For. Res. 35: 1183-1192.

Bakker M.R., Augusto L., and Achat D.L., 2006. Fine root distribution of trees and understory in mature stands of maritime pine (Pinus pinaster) on dry and humid site. Plant soil 286 : $37-51$.

Bergeret H., 1980. Évolution floristique et poductivité de Landes à molinie (Molinia coerulea M.) en forêt landaise, Doctorat, Université de Bordeaux III, France, 154 p.

Binkley D. and Graham R.L., 1981. Biomass, production, and nutrient cycling of mosses in an old-growth Douglas-fir forest. Ecology 62: $1387-1389$.

Byrne S.V. and Wentworth T.R., 1988. Relationship between volume and biomass of early successional vegetation and the prediction of Loblolly pine seedling growth. For. Sci. 34: 939-947.

Chessel D., Dufour A.-B., and Thioulouse J., 2004. The ade4 package-IOne-table methods. R News 4: 5-10.

Clary W.P. and Tiedemann A.R., 1986. Distribution of biomass within small tree and shrub form Quercus gambelii stands. For. Sci. 32: $234-242$

Dawson T.P., North P.R.J., Plummer S.E., and Curran P.J., 2003. Forest ecosystem chlorophyll content: implications for remotely sensed estimates of net primary productivity. Int. J. Rem. Sens. 24: 611-617.

Delzon S., 2000. Photosynthèse de la molinie (Molinia caerulea (L.) Moench) en sous-bois de pin maritime, aux niveaux de la feuille et du couvert, DEA (MSc), Université d'Orsay, Paris XI, 35 p.
Delzon S., Bosc A., Cantet L., and Loustau D., 2005. Variation of the photosynthetic capacity across a chronosequence of maritime pine correlates with needle phosphorus concentration. Ann. For. Sci. 62: $537-543$.

Delzon S., Bosc A., Porté A., Burlett R., Bernier F., Lambrot C., Trichet P., Sartore M., Berbigier P., Bonnefond J.-M., Medlyn B.E., and Loustau D., 2003. Closing the carbon balance of a mature pine forest. In: CarboEurope Project Meetings and CarboEurope Conference, "The continental carbon cycle", Lisbon, Portugal.

Delzon S. and Loustau D., 2005. Age-related decline in stand water use: sap flow and transpiration in a pine forest chronosequence. Agric. For. Meteorol. 129: 119.

Demounem R. and Legigan P., 1988. Les Landes et l'homme. Évolution naturelle et évolution dirigée des landes de Gascogne, Centre d'animation du Graoux (Ed.), Belin-Beliet, France, 144 p.

Den Ouden J., 2000. The role of bracken (Pteridium aquilinum) in forest dynamics, Ph. D. thesis, Landbouw universiteit Wageningen (Wageningen Agricultural University), Wageningen, The Netherlands, $221 \mathrm{p}$.

Den Ouden J. and Alaback P.B., 1996. Successional trends in biomass of mosses on windthrow mounds in the temperate rainforests of Southeast Alaska. Vegetatio 124: 115-128.

Duchemin B., Guyon D., and Lagouarde J.-P., 1999. Potential and limits of NOAA-AVHRR temporal composite data for phenology and water stress monitoring of temperate forest ecosystems. Int. J. Rem. Sens. 20: $895-917$.

Dupouey J.-L., Pignard G., Badeau V., Thimonier A., Dhote J.F., Nepveu G., Berges L., Augusto L., Belkacem S., and Nys C., 2000. Stocks et flux de carbone dans les forêts françaises. Rev. For. Fr. LII: 139-154.

Etienne M., Legrand C., and Armand D., 1991. Stratégies d'occupation de l'espace par les petits ligneux après débroussaillement en région méditerranéenne française. Exemple d'un réseau de pare-feu dans l'Esterel. Ann. Sci. For. 48: 667-677.

Fernandes P., Loureiro C., Botelho H., Ferreira A., and Fernandes M., 2002. Avaliacao indirecta da carga de combustivel em pinhal bravo. Silva Lusitana 10: 73-90.

Ford E.D. and Newbould P.J., 1977. The biomass and production of ground vegetation and its relation to tree cover through a deciduous woodland cycle. J. Ecol. 65: 201-212.

Guinaudeau J., 1964. La forêt landaise, INRA Station de Recherches Forestières, Bordeaux, France, 39 p.

IFN, 2006. Les résultats publics, Inventaire Forestier National, http:// www.ifn.fr/spip/rubrique.php3?id_rubrique $=17 \&$ script $=$ resultat. php\&web=06\&offset=2\#tab, 2th Oct. 2006.

IFN, 2007. Opérations d'inventaire, Inventaire Forestier National, http:// www.ifn.fr/spip/rubrique.php3?id_rubrique=124, 1st Sept. 2007.

Improved Pan-European indicators for sustainable forest management, 2003. Ministerial conference on the protection of forests in Europe, Vienna, Austria, 7-8 October 2002.

Kazanis D., Xanthopoulos G., and Arianoutsou M., 2006. Long-term post-fire evolution of understorey biomass in Pinus halepensis Mill. forests in Central Greece. In: Vth International Conference on Forest Fire Research, pp. 1-13.

Kubicek F. and Jurko A., 1975. Estimation of the above-ground biomass of the herb layer in forest communities. Folia Geobot. Phytotox. 10: $113-129$.

Lakida P., Nilsson S., and Svidenko A., 1996. Estimation of forest phytomass for selected countries of the former european USSR. Biomass Bioenergy 11: 371-382.

Law B.E., Van Tuyl S., Cescatti A., and Baldocchi D.D., 2001. Estimation of leaf area index in open-canopy ponderosa pine forests at different 
successional stages and management regimes in Oregon. Agric. For. Meteorol. 108: 1-14.

Lemoine B., Bonhomme D., Chinzi D., Comps B., Bergeret H., Gelpe J., Juste C., and Menet M., 1983. Élevage en forêt dans les Landes de Gascogne. I. - Le système végétal. Ann. Sci. For. 40: 3-40.

Lin K.C., Wang C.P., Huang C.M., Horng F.W., and Chiu C.M., 2003. Estimates of biomass and carbon storage in two Taiwania plantations of the Liukuei experimental forest. Taiwan J. For. Res. 18: 85-94.

Maarel E.v.d., 2005. Vegetation ecology - an overview. In: Maarel E.v.d. (Ed.), Blackwell Science Ltd., Victoria, Australia, pp. 2-51.

Magnani F., Mencuccini M., Borghetti M., Berbigier P., Berninger F., Delzon S., Grelle A., Hari P., Jarvis P.G., Kolari P., Kowalski A.S., Lankreijer H., Law B.E., Lindroth A., Loustau D., Manca G., Moncrieff J.B., Rayment M., Tedeschi V., Valentini R., and Grace J., 2007. The human footprint in the carbon cycle of temperate and boreal forests. Nature 447: 848-852.

Martin J.L., Gower S.T., Plaut J., and Holmes B., 2005. Carbon pools in a boreal mixedwood logging chronosequence. Global Change Biol. 11: $1883-1894$.

McDonald P.M., Abbott C.S., and Fiddler G.O., 2003. Density and development of Bracken Fern (Pteridium aquilinum) in forest plantations as affected by manual and chemical application. Native Plants J. 4: 53-60.

Muukkonen P., Makipaa R., Laiho R., Minkkinen K., Vasander H., and Finer L., 2006. Relationship between biomass and percentage cover in understorey vegetation of boreal coniferous forests. Silva Fenn. 40: 231-245.

Paton D., Nunez J., Bao D., and Munoz A., 2002. Forage biomass of 22 shrub species from Monfrague Natural Park (SW Spain) assessed by log-log regression models. J. Arid Environ. 52: 223-231.

Pieper R.D., 1990. Overstory-understory relations in pynion-juniper woodlands in New Mexico. J. Rangeland Manage. 43: 413-415.

Poissonnet M., Orazio C., and Carnus J.M., 2007. Projet FORSEE Un réseau de zones pilotes pour la gestion durable des forêts de l'Arc Atlantique - Partie 2: Matériel et Méthodes, Rapport final Aquitaine, European Union and FEDER - INTERREG IIIB Atlantic Area Project FORSEE, Institut Européen de la Forêt Cultivée (www.iefc. net), Cestas, France.

Popiolek Z., 1978. Ocena stanu biomasy runa i mchow wybranych zbiorowisk lesnych w nadlesnictwie Janow Lubelski (Evaluation of the biomass of the herb layer and mosses of selected forest communities in the Janow Lubelski forest district, Poland). Annales Universitatis Mariae Curie-Sklodowska C33: 237-252.

Porté A., Bosc A., Champion I., and Loustau D., 2000. Estimating the foliage area of Maritime pine (Pinus pinaster Ait.) branches and crowns with application to modelling the foliage area distribution in the crown. Ann. For. Sci. 57: 73-86.
Pyke D.A. and Zamora B.A., 1982. Relationships between overstory structure and understory production in the Grand Fir/Myrtle Boxwood habitat type of Northcentral Idaho. J. Rangeland Manage. 35: 769-773.

R Development Core Team, 2007. R: A language and environment for statistical computing, R Foundation for Statistical Computing, Vienna, Austria, http://www.R-project.org, 9th Sept. 2007.

Rameau J.C., Mansion D., Dumé G., Timbal J., Lecointe A., Dupont P., and Keller R., 1989. Flore forestière française. Guide écologique illustré, Institut pour le Développement Forestier, Paris, France, $1785 \mathrm{p}$.

Saint-Didier J., 1977a. Milieu et végétation de la grande Lande de Gascogne, DEA Analyse et aménagement de l'espace, Université de Bordeaux III, France, 38 p.

Saint-Didier J., 1977b. Phytogéographie et typologie des Landes atlantiques européennes, DEA Analyse et aménagement de l'espace, Université de Bordeaux III, France, 45 p.

Sebei H., Albouchi A., Rapp M., and El-Aouni M.H., 2001. Évaluation de la biomasse arborée et arbustive dans une séquence de dégradation de la suberaie à Cytise de Kroumirie (Tunisie). Ann. For. Sci. 58: $175-191$.

Smith W.B. and Brand G.J., 1983. Allometric biomass equations for 98 species of herbs, shrubs, and small trees, Research Note NC-299, USDA, Forest Service, North Central Experiment Station, 8 p.

Telfer E.S., 1972. Understory biomass in five forest types in southwestern Nova Scotia. Can. J. Bot. 50: 1263-1267.

Ter Mikaelian M. and Korzukhin M.D., 1997. Biomass equations for sixty-five North American tree species. For. Ecol. Manage: 97: 1-24.

Timbal J. and Caze G., 2003. Inventaire des habitats forestiers du site pilote du bassin versant de Canteloup, http://www.pierroton.inra.fr/ IEFC/activites/FORSEE/rapports/FORSEE_Aquitaine.C4.flore.pdf, 14th Oct. 2005.

Tremblay N.O. and Larocque G.R., 2001. Seasonal dynamics of understory vegetation in four eastern Canadian forest types. Int. J. Plant Sci. 162: 271-286.

Yarie J. and Mead B.R., 1988. Twig and foliar biomass estimation equations for major plant species in the Tanana river basin of interior Alaska, Research-Paper PNW-RP-401, USDA, Forest Service, Pacific Northwest Research Station, 20 p.

Zianis D. and Mencuccini M., 2003. On simplifying allometric analyses of forest biomass. For. Ecol. Manage. 187: 311-332.

Zianis D., Muukkonen P., Makipaa R., and Mencuccini M., 2006. Biomass and stem volume equations for tree species in Europe. Silva Fennica Monographs 4: 1-63. 